\title{
EMPLOYABILITY SKILLS OF VOCATIONAL SCHOOL STUDENTS IN PALU CITY FOR ENTERING THE WORK WORLD
}

\author{
Pusriawan \\ Universitas Negeri Yogyakarta \\ Sunaryo Soenarto \\ Universitas Negeri Yogyakarta
}

\begin{abstract}
This study aims to determine how much the level of employability skills of students of State Vocational Schools in Palu City. This type of research is a type of survey that is to describe the attitudes, behaviors, and opinions of students' research employability skills using a quantitative deskriptive approach, then the results of data analysis are described qualitatively, then presented in graphs, diagrams, tables, mean, modes, medians, standard deviation and variant. The population in this study was 1,275 students with a study sample of 295 students. The data collection technique used is using a questionnaire. The results of the study indicate that the level of employability skills of vocational students in Palu is generally categorized as very high. The high level of employability skills of students in the State Vocational School in Palu should be a supporting factor for students to get decent work and in accordance with their competency skills so that stakeholders, especially the school must really use it well.
\end{abstract}

Keywords: descriptive, employability skills, work world

Permalink: http://dx.doi.org/10.21831/jpv.v9i1.23351

Contact Pusriawan uci7277@gmail.com Universitas Negeri Yogyakarta, Jl. Colombo No. 1, Depok, Sleman 55281, Yogyakarta, Indonesia 


\section{INTRODUCTION}

The progress of economy and technology in this era of globalization increasingly demands the availability of qualified and competent Human Resources (HR) in all business sectors in order to be able to face increasingly sharp competition. This development also makes changes in the world of work. Simple and manual knowledge-based jobs are replaced with jobs that require the skill of applying complex knowledge and communication. Billet (Sudira, 2016) said: There are 4 things that need to be considered related to changes in the world of work and working life, namely: (1) what types of jobs are available; (2) how everyone can participate in the work; (3) what competencies are needed in work; (4) whether they can participate well in the work. Therefore how to anticipate developments and changes in the world of work is a necessity. One important sector to consider in facing the challenges of globalization is the education sector. This sector is expected to play a role in providing services, especially producing graduates who have excellence and are able to compete in global situations.

Education is an important aspect that is the main need of every human being. Education creates a change in attitude and ethics in a person. These changes start from the less good to be the better, from the less understanding to the more understanding, and so on. The problem of education is a problem that concerns the interests of all people, not only concerning investment and the condition of the nation in the present, but the impact will be felt in the future (Kuncoro, 2009, p. 2). Through education programs, Indonesian people can improve their competence in various fields and development sectors, especially in the world of education where graduates must be able to compete with other nations and be ready to fill existing jobs.

Vocational High School (Sekolah Menengah Kejuruan/SMK) is substantially one of the educational institutions that aims to produce graduates who are ready to work, entrepreneurial, intelligent, competitive, and have national identity and are able to develop local excellence and be able to compete in the global market. The vocational education system is required to produce learning outcomes that are in accordance with the needs of the workforce
(Wagiran, 2009). These objectives are listed in the National Education System Law No. 20 of 2003 Article 15 which mentions the specific objective of Vocational Schools is to prepare students to become productive human beings, able to work independently, fill job vacancies in the business world and the industrial world as middle-level workforce in accordance with the competencies in the chosen expertise program. Clark \& Winch (2007) states that vocational education is an effort to develop social workforce, maintain, accelerate, and improve the quality of a particular workforce in order to increase community productivity.

The vocational education curriculum is specifically designed to facilitate students to be able to master a field of expertise both in hard skills and soft skills aspects in the hope of becoming HR who are ready to enter the workforce and engage in community life, and have a good attitude and in accordance with the prevailing norms in society. The employment sector in Indonesia in general there are still gaps that occur between skills possessed by employers and industrial needs. This can be proven by the still high proportion of unemployment rates for SMK graduates. Based on data from the Central Bureau of Statistics (BPS), central Sulawesi shows that the data on the number of open unemployment rates (TPT) of SMK is the second largest contributor, this number will always increase because every year every vocational school, especially in the city of Palu will surely pass its students there are thousands, but not all graduates can be accommodated in the workforce.

Vocational education is believed to have a large contribution to the development of society and the improvement of the economy of a country. State competitiveness depends a lot on workers who have the knowledge and skills, because they will increase efficiency and value added production. Vocational education and training in essence is a place to prepare a knowledgeable, skilled, and personable workforce to meet the expectations of the world of work and industry. But the real conditions show that many graduates of vocational education do not get work, even those who have worked face a problem of skills. Provision of knowledge and skills they have is not enough to be able to sustain in the work environment. One of the reasons is because the workforce does not have sufficient employability skills 
such as the demands of the workforce. For this reason, vocational education institutions are expected to anticipate developments in the workforce precisely through various learning approaches to be more flexible in responding to the rapidly changing demands of the workforce.

The problem of educated unemployment compared to educated non-unemployed is precisely the more complex educated unemployment. This is because unemployed non-educated people are willing to work in the nonformal sector, while educated unemployed are equipped with the knowledge they have to work in the formal sector to get high salaries and 'prestige' in the community.

In fact, the learning process in SMK prioritizes the formation of Hard skills as a provision given to graduates to be able to compete in the workforce. Hard skills are technical skills that can be measured and observed. Every vocational school graduate should have hard skills as well as soft skills. Soft skills are non-technical skills that are important for SMK graduates. Soft skills allow a person to adjust to work they have not mastered. On the other hand, activities carried out in the industry are not only using technical skills, but also there are activities of interaction with others. People are required to work together with one another. Vocational graduates are also required to solve problems that arise in the workplace. In addition, SMK graduates are also required to be able to manage themselves and develop themselves to have good careers. Therefore, soft skills are a necessity to produce competent vocational graduates. One form of soft skills is employability skills. Employability skills are non-technical skills needed by each individual, both job seekers and workers themselves, that can be transferred and learned through both habituation and training. Employability skills are general in nature and across all types of industries, business sizes, and employment levels ranging from entry level workers to the highest positions (Robinson, 2000).

The empirical facts show that the goal of implementing vocational education has not been achieved. Not all vocational graduates can meet the demands of employment according to their specialization. This is caused by a gap between the skills possessed by vocational graduates and the skills needed in the industrial world. Provision of skills and knowledge acquired at school is not enough to answer the needs of the workforce. According to Hanafi (2012), there are several factors that are identified as being problems that are not absorbed by graduates of vocational education, including: (1) the information obtained is not sufficiently supportive for obtaining employment; (2) industries generally look for experienced workers; (3) industry complaints that many SMK graduates do not have appropriate skills, especially employability to survive and survive in various situations and working conditions.

The characteristics of the world of work and the qualifications of labor needed by the industry in the XXI century are changing rapidly (Tome, 2007, p. 336). This change is caused by the rapid development of technology. The impact of this technological development not only increases work efficiency, but also affects changes in the workplace, how to work, the formation of work organization structures, and will bring more competitive competition. According to Rojewski in Hanafi (2014) there are four changes in the current workplace, namely (1) a shift from quantity to quality; (2) increased competition for labor; (3) data processing with information technology; (4) restructuring in the workplace.

One of the characteristics of the XXI century industry is the increasing need for generic skill attributes that must be possessed by workers (Gibb, 2004). Employability skills set by UNESCO (2012) as an important skill for implementing and maintaining one's job. They need a variety of skills that can be transferred and adapted to work and environmental needs. Employability skills include problem analysis and choosing the right solution, communicating effective ideas and information, being creative, showing leadership and awareness, and showing entrepreneurial abilities. Research conducted by Hanafi (2012) states that many vocational education graduates do not get jobs because they do not have skills, one of which is employability skills. Therefore, work-oriented education through the mastery of technical skills and employability skills is needed to sustain economic development in the XXI century (Esposto \& Meagher, 2007).

Employability skills are a skill that must be owned by a prospective workforce and also people who have worked. Bennett (2006) states that the biggest challenge in the world of vocational education is to produce graduates who 
have academic skills, abilities in mastering specific skills (technical skills), and balanced employability skills. Sudana (Hartiningtyas, Purnomo, \& Elmunsyah, 2016) Vocational graduates can become skilled and qualified workforce if they truly master the hard skills and soft skills aspects. Hard skills aspects are technical skills, while soft skills are behavioral skills. Hard skills and soft skills are formed through the learning process in accordance with the competence of their skills, both during class hours and outside of school hours. The formation of attitudes that support aspects of students' employability skills requires a periodic and continuous process that is massive and comprehensive, so that vocational graduates can meet the standards needed by the workforce and industry and become professional workforce.

Sudira $(2011$, p. 43) in his dissertation downgraded the definition of employability skills into a set of non-technical and transferable skills needed to obtain, maintain, and develop one's career in the workplace. Employability skills have a transferable nature which means that employability skills can be used under any circumstances. As an example of problem solving as one aspect of employability skills, one can use problem solving skills either at home, at work, or in other circumstances. This is what is meant by transferable. Employability skills are also very much needed in the era of 21st Century Skills.

In the implementation of Vocational High Schools (SMK), there are several competency skills. Determining the type of competency skill is influenced by employment opportunities or labor requirements. In Palu city there are 8 State Vocational Schools with various skill competencies which are expected to produce graduates who are ready to work in their respective fields. Based on this, the preparation of graduates in accordance with the demands of the XXI century must be sought to produce quality graduates. From the explanation that has been reviewed previously, it can be concluded that qualified graduates from educational institutions, especially Vocational Schools, which are in accordance with the demands of the XXI century industry are graduates who have high employability skills, in addition to academic abilities and technical abilities. Therefore, based on the background described, it is deemed necessary to examine the "employability skills of vocational students in the city of Palu to enter the workforce".

Based on the above problems, this study will measure aspects of employability skills possessed by vocational students in Palu City in entering the workforce by looking at how much the level of employability skills of vocational students in the city of Palu? This study aims to determine how much the level of employability skills of students of State Vocational Schools in Palu City.

\section{RESEARCH METHODS}

The type of research used is a type of survey. Research uses a quantitative approach. This research is only limited to describing how high the level of student employability skills is by presenting it in the form of diagrams and numbers with descriptions in sentence form. This study involved respondents in class XII of State Vocational Schools in Palu City who had implemented apprenticeship. The population in this study was 1,275 students with a study sample of 295 students. Then the next step is to determine the sample in each school by using Purposive Sampling technique, namely the selection of samples with certain considerations with the aim that the data obtained later can be more representative (Sugiono, 2010). The data collection technique used is using a questionnaire.

This study uses one variable described into several indicators, namely communication skills, teamwork skills, problem solving skills, skills in taking initiatives and efforts, skills in planning and managing activities, self-management skills, learning skills, technology skills, occupational health and safety skills. The research data will be analyzed descriptively. Analysis is used to calculate the mean, median, mode, standard deviation, data distribution table, and chart categories in sentences. The category according to Wagiran (2013) is divided into four, namely very high, high, medium, and low.

\section{RESULTS AND DISCUSSION}

\section{Results}

The results of the study are presented in the form of the results of calculations of central tendencies (mean, median, mode), and data distribution. Presentation of data distribution 
includes variants and standard deviations. Next is the presentation of the size of the frequency distribution and interperetation of the research data. Where the interpretation refers to four categories namely very high, high, medium and low. The description of the variable data on employability skills of students of State Vocational Schools in Palu City consists of nine aspects as follows:

\section{Communication Skills}

Communication Measurement of students of State Vocational Schools in the Palu city used questionnaires as many as 10 items. Based on the calculation results using SPSS software, the percentage of the score tendency in the communication skills aspects of the students of State Vocational Schools in Palu can be seen in Figure 1.

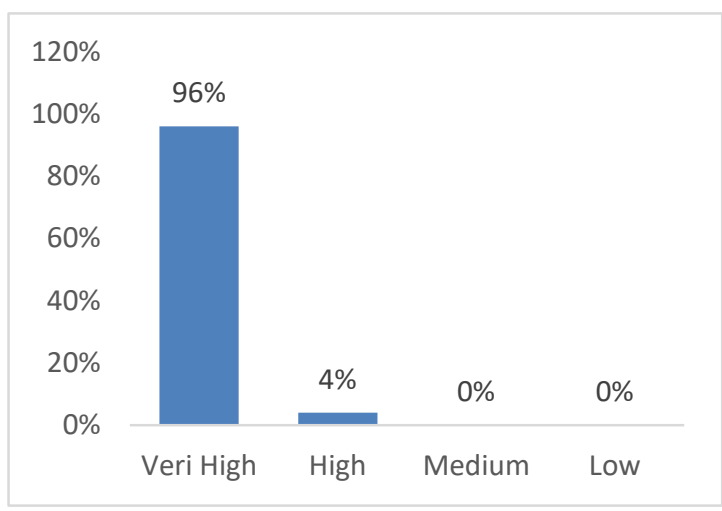

Figure 1. Communication Skills Graph

Figure 1 shows that the communication skills of state Vocational students in Palu city generally have a very high category (96\%). Achieving scores on the communication skills aspects of the students of State Vocational Schools in Palu obtained a total score of 7,887 from the highest score set at 12,920 so that the score of the communication aspect obtained a percentage of $61.04 \%$ from the score with the very high category.

\section{Collaboration Skills with TIM}

Measurement of collaboration with the team using questionnaires as many as 6 items. Based on the results of the calculation, the percentage of the tendency to score aspects of the skills of cooperation with the team in students of State Vocational Schools in the city of Palu can be seen in Figure 2.

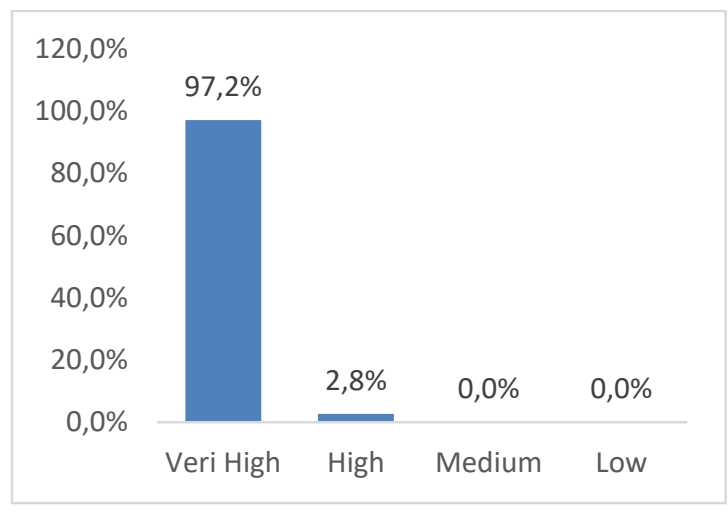

Figure 2. Graph of Teamwork Skills

Figure 2 shows that the aspect of collaboration skills with the team of state vocational students in the Palu city in general has a very high category $(97.2 \%)$. The achievement of scores on aspects of cooperation skills with the team obtained a total score of 5,738 from the highest score set at 7,758. so that the score of the aspect of collaboration skills with the Team obtained a percentage of $74.02 \%$ of the score in the very high category.

\section{Problem Solving Skills}

Measurement of problem solving skills using a questionnaire of 7 items. Based on the results of the calculation, the percentage of score tendency aspects of problem solving skills by students of State Vocational Schools in the city of Palu can be seen in Figure 3.

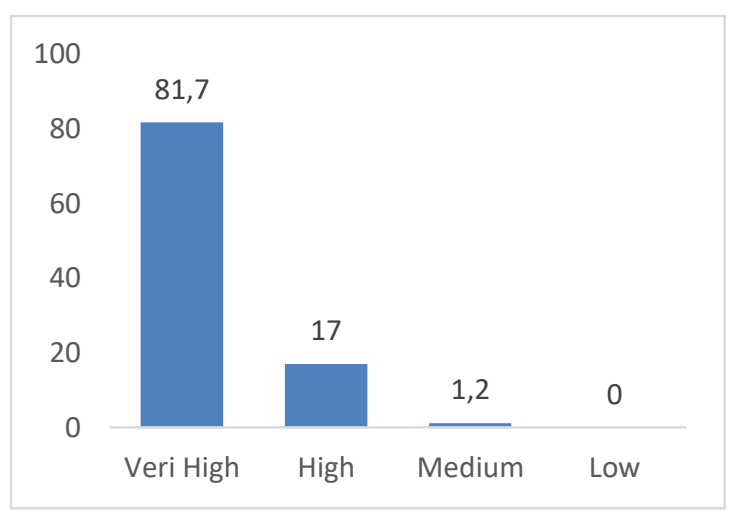

Figure 3. Problem Solving Skills Diagram

Figure 3 shows that the aspects of problem solving skills by students of State Vocational Schools in the Palu city in general have a very high category $(81.7 \%)$. The achievement of the score of the problem solving skills aspect by the students of the State Vocational School in Palu obtained a total score of 5,830 from the highest score set at 9,044, so that the score of 
the problem solving skills gained a percentage of $64.46 \%$ from the score with very high category.

\section{Skills in Taking Initiatives and Trying}

Skill measurement in taking initiatives and trying to use a questionnaire of 5 items. Based on the results of the calculation, the percentage of the score tendency of Skills aspects in taking initiatives and endeavors by students of State Vocational Schools in the city of Palu can be seen in Figure 4.

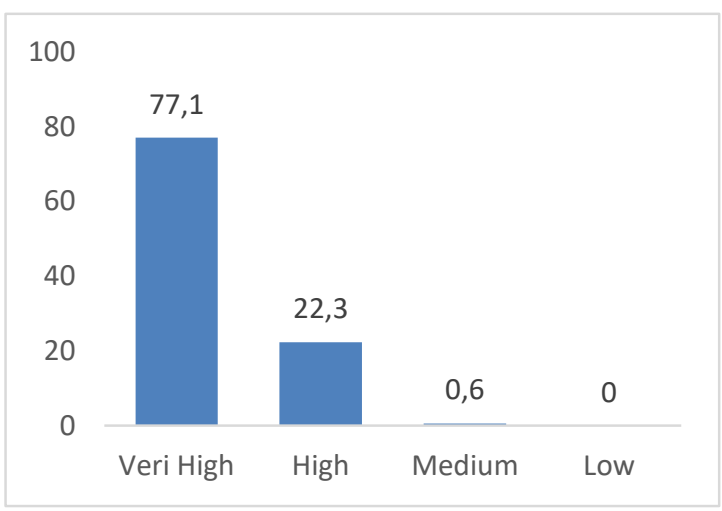

Figure 4. Skills Diagram in Taking Initiatives and Trying

Figure 4 shows that the Skills aspect in taking initiatives and endeavors by state Vocational School students in the Palu city in general has a very high category $(77.1 \%)$. Achieving the Skills aspect score in taking initiatives and efforts by the students of State Vocational Schools in Palu obtained a total score of 4,120 from the highest score set at 6,460 , so that the skills aspect score in taking the initiative and trying to obtain a percentage of $63.78 \%$ of scores with very high categories.

\section{Skills Aspects Plan and organize Activities}

Measuring skills for planning and organizing activities using questionnaires as many as 5 items. Based on the results of the calculation, the percentage trend score aspects of the skills of planning and organizing activities by students of State Vocational Schools in the city of Palu can be seen in Figure 5.

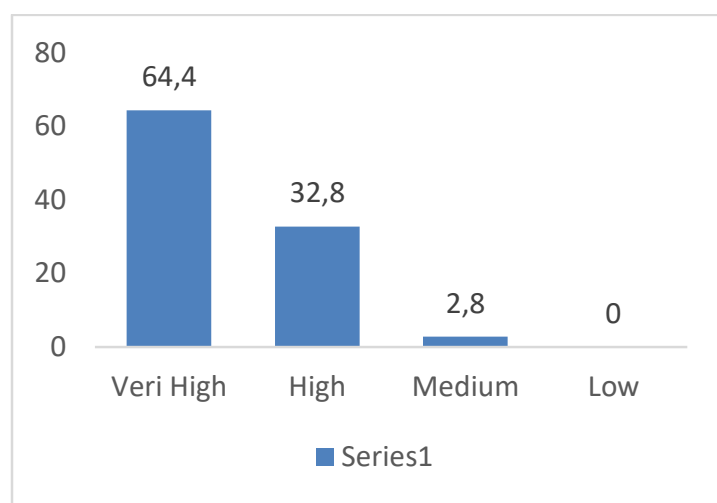

Figure 5. Skills Diagram for Planning and Organizing Activities

Figure 5 shows that the Skills aspect of Planning and organizing Activities by State Vocational School students in the Palu city in general has a very high category (64.4\%). Achieving Skills aspect scores Planning and organizing Activities by State Vocational High School students in Palu city obtaining a total score of 4,222 from the highest score set at 6,460 , so the Skill Aspect Planning and organizing activities score gets a percentage of $65.36 \%$ of the scores with very high categories. Percentage of score tendencies Skills Aspects Planning and managing activities can be seen in Figure 5.

\section{Self Management Skills}

Measurement of self-management skills using questionnaires as many as 9 items. Based on the results of the calculation, the percentage of the tendency to score aspects of the skills of Self-Managing skills by students of State Vocational Schools in the city of Palu can be seen in Figure 6.

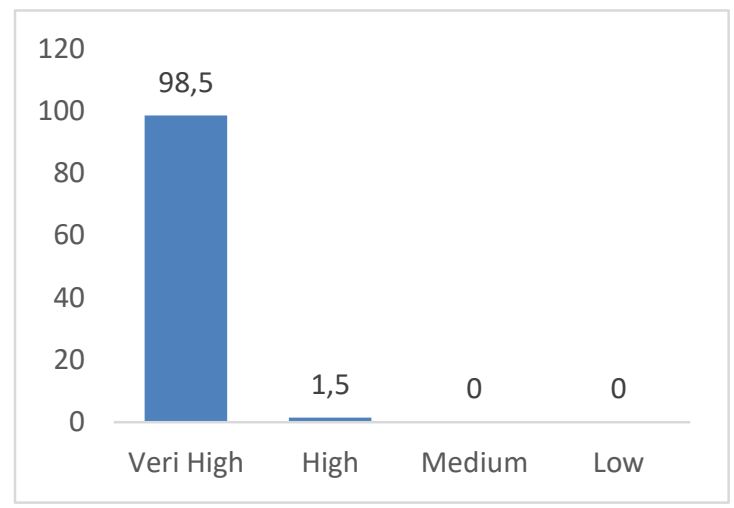

Figure 6. Self Management Skills Diagram 
Figure 6. shows that the aspects of selfmanagement skills by students of State Vocational Schools in the Palu city generally have a very high category $(98.5 \%)$. The achievement of the score aspects of the self-managing skills of the students of the State Vocational School in Palu obtained a total score of 8,506 from the highest score set at 6,460 , so that the score on the aspects of self-management skills obtained a percentage of $73.15 \%$ from the score with very high category.

\section{Skills in Learning}

Measurement of skills in learning using questionnaires as many as 7 items. Based on these results, the percentage of the tendency to score skills aspects in student learning by students of State Vocational Schools in the city of Palu can be seen in Figure 7.

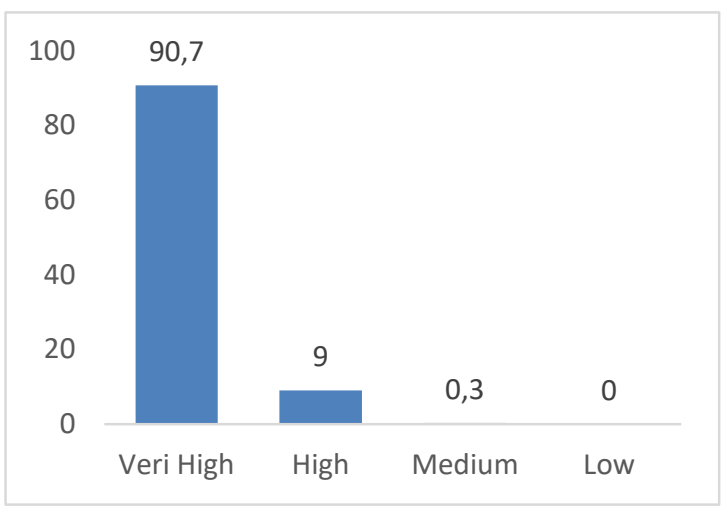

Figure 7. Skills in learning diagrams

Figure 7. shows that the skills aspect of learning by students of State Vocational Schools in the Palu city in general has a very high category $(90.7 \%)$. Achieving the score of the skill aspect in student learning at the State Vocational School in Palu obtained a total score of 8,506 from the highest score set at 6,460 , so the score in the learning skills aspect gained a percentage of $73.15 \%$ from the score with the very high category.

\section{Skills in Using Technology}

Measuring skills using technology uses a questionnaire of 7 items. Based on the results of the calculation, the percentage of the tendency to score the skills aspects of using technology by students of State Vocational Schools in the city of Palu can be seen in Figure 8.

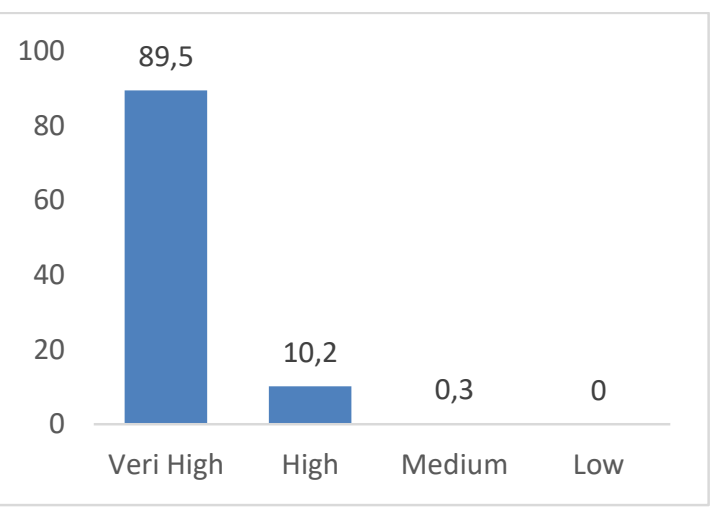

Figure 8. A skill diagram using technology

Figure 8. shows that the skills aspect of using technology by students of Public Vocational Schools in the Palu city in general has a very high category (90.7\%). Achieving the score of the skill aspect using technology obtained a total score of 6,364 from the highest score set at 9,044, so that the score of the skill aspect using technology obtained a percentage of $70.37 \%$ of the score with a very high category.

\section{Occupational health and safety skills}

Measurement of occupational health and safety skills using questionnaires as much as 4 items. Based on these results, the percentage trend score of the skill aspects of using technology by students of State Vocational Schools in the city of Palu can be seen in Figure 9.

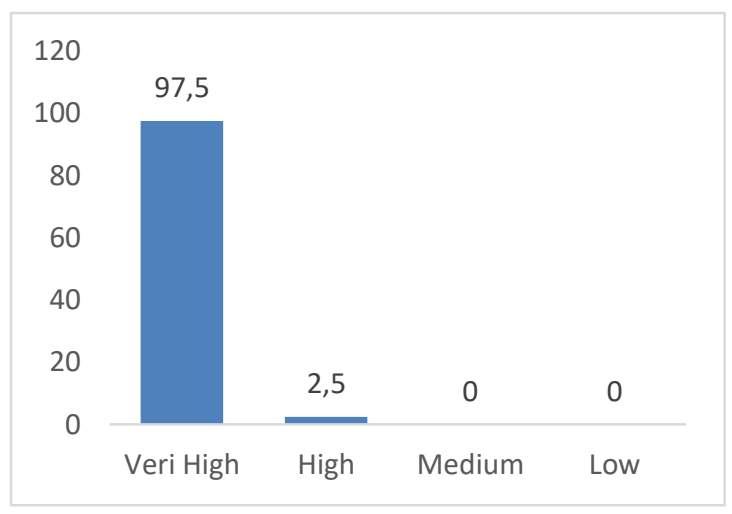

Figure 9. Skills diagram using technology

Figure 9. shows that aspects of occupational health and safety skills generally have a very high category $(97.5 \%)$. The achievement of the score on the aspects of occupational health and safety skills of the students of the State Vocational School in Palu obtained a total score of 4,060 from the highest score set at 5,168 , so that the score on the skill aspect 
using technology received a percentage of $78.56 \%$ from the very high category.

Table 1. Comparison of the Aspect Levels of Employability Skills of State Vocational School Students in Palu City

\begin{tabular}{lccc}
\multicolumn{1}{c}{ Skills } & Mean & $\begin{array}{c}\text { The mean } \\
\text { is divided } \\
\text { by mom }\end{array}$ & Rangk \\
\hline $\begin{array}{l}\text { Occupational health and } \\
\text { safety skills }\end{array}$ & 12,6 & 3,14 & 1 \\
$\begin{array}{l}\text { Collaboration Skills with } \\
\text { TIM }\end{array}$ & 17,8 & 2,96 & 2 \\
$\begin{array}{l}\text { Self Management Skills } \\
\text { Skills in Learning }\end{array}$ & 26,3 & 2,93 & 3 \\
$\begin{array}{l}\text { Skills in Using Technology } \\
\text { Skills Aspects Plan and }\end{array}$ & 19,9 & 2,84 & 4 \\
organize Activities & 13,1 & 2,81 & 5 \\
$\begin{array}{l}\text { Problem Solving Skills } \\
\text { Skills in Taking Initiatives } \\
\text { and Trying }\end{array}$ & 18,05 & 2,58 & 7 \\
Communication Skills & 24,4 & 2,44 & 9 \\
\hline
\end{tabular}

If sorted according to the highest average value to the lowest average value, the levels of the student's skills in order are occupational health and safety skills, teamwork, self-management, learning, using technology, planning and organizing activities, solving problems, take initiative and effort and communication.

\section{Discussion}

The results of the study indicate that the level of employability skills of vocational students in Palu is generally categorized as very high. If viewed from the level of vocational student employability skills in each aspect, the highest employability skill of the SMK students in the Palu is in the aspect of occupational health and safety skills with an average value of 3.14; and the lowest aspect of the employability skill is in the communication aspect with an average value of 2.44 .

The results showed the highest aspects of the employability skills of state Vocational High School students in Palu city were occupational health and safety aspects. This is possible for this aspect to be easier to be taught and trained to students in the learning process. Likewise the aspects of teamwork, self-management, learning, using technology and communication which are the next ranks. As with the aspects of planning and managing activities, solving problems, taking precursors and trying. These aspects are strongly influenced by high-level thinking skills (HOTS). This really depends on the level of students' ability to develop these skills.

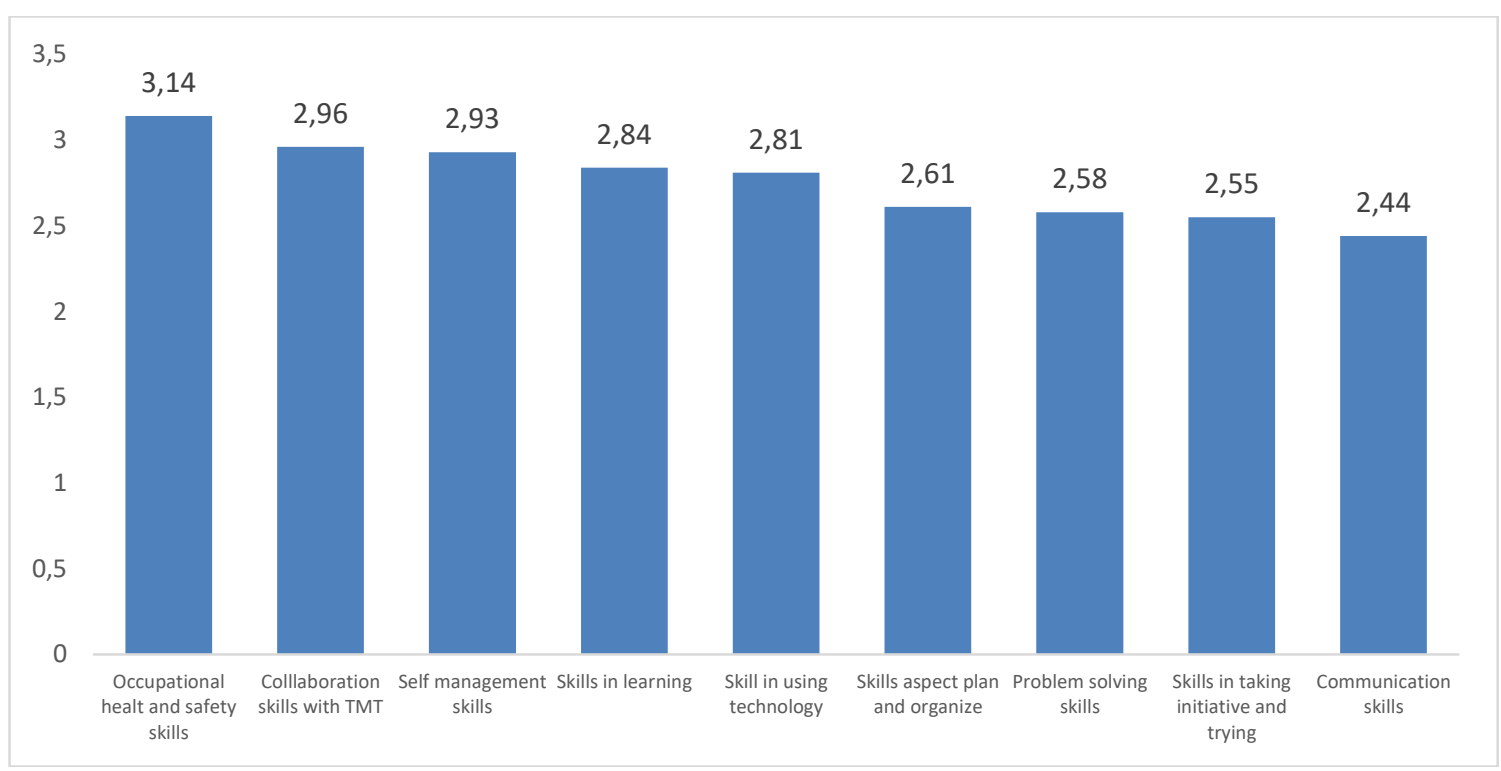

Figure 10. Graph of Comparison of Aspect Levels of Employability Skills of Vocational School Students in Palu City 
At present the world of work requires workers who not only have technical skills, but also employability skills. Indeed aspects of employability skills can be taught and developed in the classroom environment through the right learning approach. This is in accordance with the research conducted by Philip et al. (2015) which states that at the beginning of the curriculum, employability skills can be developed through learning where the curriculum compilers are required to participate in DUDI. Asonitou (2015) explains that attitudes, methods and practices need to be re-examined in relation to teaching and learning approaches, assessment and work-based education.

As the results of the research conducted by Lane (2016), that collaborative learning allows students not only academic learning, but also to develop interpersonal and group skills needed for teamwork, developing leadership skills and improving communication skills. Furthermore, according to Cleary, Flynn, Thomasson, Alexander, \& McDonald (2007) employability skills can be developed through academic assignments, work practices, industry-based learning, and cooperative learning integrated with work. In addition, it can also be done in various activities such as work experience, problem-based learning, and projectbased learning (Smith \& Comyn, 2003). Human factors or attitudes of educators and students who are directly involved to ensure the success of the learning process will make students see, understand and be confident in applying knowledge. This will benefit students before entering the work environment after graduation because they can have many employability skills. Gowsalya \& Kumar (2015) in their study stated that work skills are needed. Being clever in one skill cannot facilitate other competencies. Therefore a job applicant must be multi-tasking in getting and maintaining a job. Kavoura (2013) explained that the way to communicate students with the public in various sectors needs to be considered by organizations and countries. On the other hand Sakas, Vlachos, Nasiopoulos (2014) in his study stated that Technology underlies the development of competitive advantage.

\section{CONCLUSION}

The level of employability skills of vocational students in Palu is generally cate- gorized at a very high level. If viewed from the level of vocational student employability skills in each aspect, the highest employability skill of the SMK students in Palu is in the aspect of occupational health and safety skills with an average value of 3.14; and the lowest aspect of the employability skill is in the communication aspect with an average value of 2.44 . The high level of employability skills of the students of State Vocational Schools in Palu should be a supporting factor for students to get decent work and in accordance with their competency skills so that stakeholders can really use it well.

\section{REFERENCES}

Bennett, T. M. (2006). Defining the importancei of employability skills in career/technical education. Dissertation (unpublished). Auburn, Alabam: the Graduate Faculty of Auburn University

Clark, L. \& Winch, C. (2007). Vocational Education International Approaches, Developments and Sistems. New York: Routledge.

Cleary, M., Flynn, R., Thomasson, S., Alexander, R., \& McDonald, B. (2007). Graduate employability skills: Prepared for the business, industry and higher education collaboration council. Melbourne: Precision Consultancy.

Esposto, A., \& Meagher, G.A. (2007).The future demand for employability skills and the implications for the VET system. Rereieved 27 October 2017 from http://www.avetra.org.au/publications/12 -Esposto.pdf

Gibb, J. (2004). Generic skills in vocational education and training. Adelaide SA: National Centre for Vocational Education Research Ltd

Gowsalya, G., \& Kumar, A. (2015). Employability Skill: A Literature Review. International Journal of Advance Research in Computer Science and Management Studies, 3(3) 353-360

Hanafi, I. (2012). Re-orientasi keterampilan kerja lulusan pendidikan kejuruan. Jurnal Pendidikan Vokasi, 2(1). doi:https://doi.org/10.21831/jpv.v2i1.10 
21

Hanafi, I. (2014). Pendidikan teknik dan vokasional: Menggali pengalaman sukses Institusi Bi-National di negeri Jiran, dari konsep hingga implementasi. Bandung: Refika Aditama

Hartiningtyas, L., Purnomo, \& Elmunsyah, H. (2016). Hubungan antara self regulated learning dan locus of control internal dengan kematangan vokasional siswa SMK. Jurnal Pendidikan: Teori, Penelitian, dan Pengembangan, 1(6). 1127-1136

Kavoura, A. (2013). Politics of Heritage promotion: Branding the identity of the Greek state. Tourism Culture and Communication, 12, 69-83.

Kuncoro. (2009). Pendidikan dan Pembelajaran. Surakarta: Media Citra Lestari.

Robinson, J. P. (2000). What are employability skills?. The Workplace, 1(3). Retrieved 10 September 2017 from http://stlwebdev.us/careerdev/documents /Employability-Skills.pdf

Sakas, D., Vlachos, D., \& Nasiopoulos, D. (2014). Modelling strategic management for the development of competitive advantage, based on technology. Journal of Systems and Information Technology. 187 - 209.

Smith, E. \& Comyn, P. (2003). The development employability skills in novice workers. Adelaide, Australia: National Centre for Vocational
Education Research.

Asonitou, S. (2015). Employability Skills in Higher Education and the Case of Greece. Procedia - Social and Behavioral Sciences, 175. 283 - 290.

Sudira, P. (2016). TVET ABAD XXI Filosofi, Teori, Konsep, dan Strategi Pembelajaran Vokasional. Yogyakarta: UNY Press.

Sudira, P. (2011). Praksis Ideologi Tri Hita Karana Dalam Pembudayaan Kompetensi Pada Smk di Bali. Disertasi, tidak diterbitkan, Universitas Negeri Yogyakarta, Yogyakarta.

Sugiyono. (2010). Metode penelitian pendidikan, Pendekatan kuantitatif, kualitatif dan $R \& D$. Bandung: Alfabeta.

Tome, E. (2007). Employability, Skills, and Training in Portugal (1988-2000): Evidance from Official Data. Journal of European Industrial Training, 31(5), 336-357.

UNESCO. (2012). Youth and skills: putting education to work. Paris: UNESCO Publishing

Wagiran (2009). Paradigma peningkatan mutu lulusan SMK melalui integrasi soft skills untuk menghasilkan lulusan unggul dan berdaya saing. In Seminar Nasional Paradigma Baru Mutu Pendidikan di Indonesia, Lembaga Penelitian Universitas Negeri Yogyakarta

Wagiran. (2013). Metodelogi penelitian Pendidikan: Teori dan Implementasi. Yogyakarta: Deepublish. 